\title{
China's Labour Contract Law and Labour Costs of Production
}

Zhaozhou Han, Vincent Mok, Lina Kong and Kang An

\section{(2) OpenEdition \\ Journals}

Electronic version

URL: http://journals.openedition.org/chinaperspectives/5648

DOI: 10.4000/chinaperspectives.5648

ISSN: 1996-4617

\section{Publisher}

Centre d'étude français sur la Chine contemporaine

Printed version

Date of publication: 1 October 2011

Number of pages: $59-66$

ISSN: 2070-3449

\section{Electronic reference}

Zhaozhou Han, Vincent Mok, Lina Kong and Kang An, «China's Labour Contract Law and Labour Costs of Production », China Perspectives [Online], 2011/3 | 2011, Online since 30 September 2014. connection on 28 October 2019. URL : http://journals.openedition.org/chinaperspectives/5648; DOI : 10.4000/chinaperspectives.5648 


\title{
China's Labour Contract Law and
}

\section{Labour Costs of Production}

\author{
ZHAOZHOU HAN, VINCENT MOK, LINA KONG, KANG AN*
}

\begin{abstract}
The promulgation of the Labour Contract Law in China has aroused heated debate about the financial burden of the new labour costs for firms. However, based on a data set collected in Guangdong Province in southern China, the empirical findings suggest that, on average, the increase in labour costs per capita in the sample firms due to the effects of the law ranges between 2.54 percent and 4.90 percent, which seems to be economically insignificant. **
\end{abstract}

\section{KEYWORDS: Labour Contract Law, China, Effects, Labour Costs}

S ince the economic reforms of 1979 , China has achieved remarkable economic growth that amounts to an annual average growth rate of 9.9 percent in gross domestic product (GDP) from 1979 to 2010. (1) A major impetus of China's economic growth is based on the advantage of its low labour costs. While the state has always striven for social stability, employment creation has been the primary target. Low-value-added labour-intensive processing industries are a quick means of increasing employment opportunities. However, the laws and regulations pertinent to the labour market are not strongly enforced to protect the rights of workers. Labour conflicts often subsequently develop into collective defiance. For example, Ching-kwan Lee delineated a detailed discussion on the proliferation of labour conflicts in Shenzhen, a special economic zone in southern China, where labour grievances mainly stem from workplace degradation, exploitation, and discrimination. (2) Anita Chan (1998) explained that labour rights are violated in many areas in China, viz. (i) the lack of rights of migrant workers, (ii) forced and bonded labour, (iii) living on below-subsistence wages, (iv) intimidation, physical violence, corporal punishment, and control of bodily functions, and (v) lack of occupational health and safety. (3) BBC Asia-Pacific News (2010) highlighted that poor working conditions, lack of trade union representation, and unreasonably low wages are the common reasons for strikes in China. ${ }^{(4)}$ Nowadays, workers can easily communicate through mobile phones and instant messaging. Any discontent stemming from the above common causes of labour grievance will quickly spread among workers. Therefore, it is not uncommon to see workers set up picket lines and organise demonstrations, leading to possible social turmoil. (5)

Advancing into the twenty-first century, the Chinese government has realised that economic development in the future should not only rely on low-value-added, labour-intensive processing industries, and that job creation alone may not guarantee social stability. The government has therefore shifted its industrial development strategy to higher-technologybased industrial production and stable employment relations in the longer term for social cohesion and harmony. (6) Set against this background, the Chinese government has promulgated the Labour Contract Law (hereafter "the Law") with the aim of clearly delineating and strengthening relations between workers and firms, monitoring their behaviour, and creating ex- plicit rights and obligations for both parties. Before the promulgation of the Law, the Judiciary Committee of the Standing Committee of the National People's Congress reported that less than one fifth of enterprises had signed labour contracts with their workers. ${ }^{(7)}$ Even though some workers had entered into labour contracts with their employers, many labour contracts were rather informal. In those informal contracts, the basic rights of labourers, including minimum wages, working conditions, working hours, and social insurance provisions, were unclearly stated. Moreover, many labourers could only engage in short-term or temporary contracts with their employers. As such, their basic human rights were not adequately protected. ${ }^{(8)}$

Zhaozhou Han is Professor at the Department of Statistics of Jinan University in Guangzhou (hanzhaozhou@21cn.com); Vincent Mok is Assistant Professor at the School of Accounting and Finance of the Hong Kong Polytechnic University in Hong Kong (afvmok@polyu.edu.hk); Kang An (huan1216@yahoo.com.cn) and Lina Kong (klnmail@163.com) are both Research Officers at the Department of Statistics and Analysis of the Guangzhou Branch of People's Bank of China.

** The paper has received major support from the Guangdong Labour and Social Guarantee Bureau, China, to finance the project on "The Effects of the Labour Contract Law on Enterprises." Our gratitude also goes to the Guangdong Statistical Bureau and Guangdong Survey Brigade of China National Bureau of Statistics for their kind and valuable assistance, which facilitated our indepth questionnaire survey. Acknowledgement is due to Isom Adiari for information searches. We would like to express our heartfelt appreciation to the two anonymous reviewers who provided us with insightful comments and suggestions on an early draft of the paper. The viewpoints and findings given in this paper do not necessarily reflect those of our affiliations or of the organisations mentioned above. We retain responsibility for the opinions expressed in the paper.

1. China National Bureau of Statistics, China Statistical Yearbook, various issues.

2. Ching-kwan Lee, Against the Law: Labour Protests in China's Rustbelt and Sunbelt, Berkeley, University of California Press, 2007, Chapter 5, pp. 157-203.

3. Anita Chan, "Labor Standards and Human Rights: The Case of Chinese Workers under Market Socialism," Human Rights Quarterly, vol. 20, 1998, pp. 886-904.

4. BBC Asia-Pacific News, "China's Factories Hit by Wave of Strikes," 28 June 2010. Retrieved on 11 July 2011 (www.bbc.co.uk/news/10434079).

5. Alvin So, "Post-socialist State, Transnational Corporations, and the Battle for Labor Rights in China at the Turn of the 21st Century," Development and Society, vol. 39, no. 1, 2010, pp. 97-117.

6. On this topic, see Liisi Karindi, "The Making of China's New Labour Contract Law," China Analysis, no. 66, 2008; Yu-fu Chen and Michael Funke, "China's New Labour Contract Law: No Harm to Employment?" China Economic Review, vol. 20, no. 3, 2009, pp. 558-572; Haiyan Wang, Richard Appelbaum, Francesca Degiuli, and Nelson Lichtenstein "China's New Labour Contract Law: Is China Moving towards Increased Power for Workers?" Third World Quarterly, vol. 30, no. 3, 2009, pp. 485-501.

7. Haiyan Wang (et al.) summarised the background, passing, and voting of the Law, and the highlights of the contents of the Law. See Haiyan Wang et al., op. cit., pp. 489-491.

8. Ibid., p. 489. 
In the process of soliciting public comments on the Law, the Chinese government openly called for non-Party reviews on the legislation of the Law. The responses were very numerous, amounting to nearly 200,000 comments, among which two-thirds came from ordinary workers. A large majority of the comments were sent to the Chinese government through the Internet. ${ }^{(9)}$ Upon considering public feedback on the Law, the government amended the content of the new Labour Contract Law three times, in December 2006, April 2007, and June 2007. At the $28^{\text {th }}$ Session of the $10^{\text {th }}$ Standing Committee of the National People's Congress held in June 2007, the new Labour Contract Law was passed, and the promulgation of the Law was scheduled to be effective from the first day of 2008. The highlights of the content of the Law in the areas of fixed-term labour contracts, employee compensations upon termination or expiration of labour contract, salary issues during the probation period, and obligations and penalties on enterprises when the Law has been violated, etc., are discussed in Section 2, below.

Since its implementation on 1 January 2008, the Law has aroused heated debate. In particular, some corporate representatives have voiced strong opposition that has been noted. As the Law in principle would likely increase the labour costs of production, for example, by increasing the requirements for severance pay and providing long-service workers with protection against dismissal, etc., many firms have reacted by, for instance, planning to leave the Chinese market. Liisi Karindi reported:

According to the Federation of Hong Kong Industries, an estimated 10 per cent of the 60,000 - 70,000 factories owned by Hong Kong entrepreneurs in Guangdong will close their doors in 2008. The Wall Street Journal reported recently that some shoe companies in the Pearl River Delta area have already closed. The Taiwan Merchant Association in Dongguan estimates that at least 200 Taiwaneseowned businesses have left the area and more will probably be leaving later this year... ${ }^{(10)}$

The scenario seemed dire:

... the Shanghai-based American Chamber of Commerce lobbied hard against the employment security provisions in the proposed law and won some last-minute concessions. But these were not enough, claimed some employers, to prevent a wave of factory closures and threats of more among the most labour-intensive manufacturers of Guangdong Province. By one account 1000 footwear and accessory producers had reduced output or closed up shop. Some moved to the Chinese hinterland, others to Vietnam and Burma, where labour was cheaper... ${ }^{(11)}$

In short, firms were concerned that the Law could exert grave impact by raising labour costs, with deleterious effects on their cost competitiveness and profit margins. Was the implementation of the Law really to blame for the threatening phenomenon? Despite the on-going debate, empirical evidence of the impact of the Law on corporate labour costs of production, to the best of our knowledge, has lacked systematic academic research. Against this background, the central question posed in this paper is to examine the extent to which implementation of the Law has affected the labour costs of production. This paper focuses on this empirical question by drawing upon a data set obtained from a field survey in late 2008 conducted in Guangdong Province in southern China.
We will first introduce the statistical methods that examine the effects of the Law on labour costs. Two approaches, namely direct and indirect cost accounting methods, are adopted. Then, we will delineate the empirical findings of the effects of the Law on labour costs. At the end, we will provide some concluding remarks.

\section{Statistical methods to determine the effects of the Labour Contract Law on labour costs}

To examine the effects of the Law on the corporate labour costs of production, we adopted direct and indirect cost accounting methods in our study. Subsequently, the effects of the Law on labour costs were compiled into a range of percentiles.

\section{Analysing the effects of the Law on labour costs by using the direct cost accounting method}

To proceed with the direct cost accounting method, we first conducted a review of the main elements of the Law and compared them with other relevant regulations on labour protection. Then, we designed a questionnaire on these pertinent regulations and issues in order to obtain relevant financial and personnel data. Finally, we estimated the increase in labour costs as well as the share of the increase in labour costs to the total labour costs of production.

The direct effects on labour costs of implementation of the Law can be grouped into three areas: direct increase in labour costs, regressive costs, and costs of law violation. ${ }^{(12)}$ The explanations are as follows.

\section{Effects of the implementation of the Law on direct increases in labour costs of firms}

Direct increases in labour costs refer to (i) the economic compensation that a firm shall bear when a labour contract is terminated upon its expiration (stipulated by the Law for the first time), and (ii) salary increases during the probationary period. (13) The first component of a direct increase in labour costs is the outcome from the economic compensation as stipulated in Article 46 of the Law. The regulations under the previous labour contract law allowed firms to hire workers for a number of fixed-term contracts. In doing so, these firms would not have to pay severance compensation to workers upon termination or expiration of contract. According to Article 46 of the new law, workers with an employment record of 10 years or more will receive adequate financial compensation should they be made redundant. The economic compensation is one month of basic salary per year of service with a ceiling that amounts to 12 months of the basic salary. As for the employment terms of workers, in the past, firms in China were inclined to hire a large number of temporary workers so they could avoid paying the benefits stip-

9. Ibid., p. 490.

10. Liisi Karindi, op. cit. p. 13.

11. Haiyan Wang et al., op. cit., p. 488.

12. On this topic, see Baohua Dong, "Study on the Legislation Concept Design and Adjustment of Labor Contract Law from the Layoff Waves," China Human Resource Development, vol. 12, 2007, pp. 67-71; and Fangfang Yang, "Transformation of Corporate Human Resource Management Concept under Labor Contract Law," Economic Management, vol. 23, 2007, pp. 55-58.

13. Yu-fu Chen and Michael Funke "China's New Labour Contract Law: No Harm to Employment?" op. cit., pp. 559-560; Haiyan Wang et al., "China's New Labour Contract Law: Is China Moving Towards Increased Power for Workers?" op. cit., pp. 489-491. 
ulated under regular employment terms. However, this seems to give firms more flexibility in employment practices. ${ }^{(14)}$ In the new law, temporary workers who are paid hourly wages and work more than 24 hours a week are to be treated as regular workers. All in all, these stipulations place a greater financial burden on firms and aroused much more discontent.

The second component stems from Article 20 of the new regulations in the Law, in that the standard salary during the probationary period should be "not less than 80 percent" of the starting salary for regular workers in the same position. Moreover, probationary periods are reduced to a maximum of two months from the previous six months before the implementation of the Law. ${ }^{(15)}$

The Law has not been in effect for an extended period of time. In the future, when more labour contracts are terminated, the economic compensation involved in this aspect can be expected to increase and result in increasing operational costs for firms. Marginal firms may be eliminated, leaving efficient firms to survive. The effect of the direct increase in labour costs is likely to gradually wane over time.

\section{Effects of the implementation of the Law on the regressive costs of firms}

The so-called "regressive costs" refer to the cost of regressive differences, including social security fees, a portion of which has usually not been paid by firms. Before the promulgation of the Law, it was not uncommon for many firms to flout the state policy on paying the required amount of social security fees. Yinhua Sha reported that in 1999, 49 state-owned enterprises out of a sampling of 100 enterprises in Jiangsu and Sichuan provinces failed to pay social security fees in an amount totalling 64.82 million yuan. In Zhuzhou, Hunan Province, the collection rate of social security fees was only recorded at 88.0 percent in 1997. ${ }^{(16)}$ The rate fell to 78.2 percent in the following year. In Hainan Province in 2000 , as many as 2,760 firms failed to pay social security fees totalling 294.42 million yuan. Among others, one major reason was attributed to the underdeveloped legal system in terms of enforcement. There was no explicit legal provision to compel firms to pay social security fees. To rectify the unfair treatment of employees that pertained to social security, a serious call for the enactment of related laws was at the top of the government agenda. ${ }^{(17)}$

Article 17 of the Law requires firms to contribute to the social security accounts of their employees, and they should fulfil their obligations completely. The most apparent increase in regressive costs occurs in the total expenditure on social insurance borne by firms. In the context of China's Social Security Law, the social security framework consists of five areas of insurance, i.e., basic retirement, medical, work-related injuries, unemployment, and maternity. The framework covers all employers and employees. ${ }^{(18)}$ Along with implementation of the Law, a firm must pay social security fees in strict accordance with the stipulated rules. Article 38 of the Law stipulates that a firm failing to do so will face penalties. In contrast, firms that did not pay the fees before the Law came into effect will now incur higher labour costs when they fulfil their obligations to pay the fees. Moreover, as regards the effects of regressive costs on labour costs, attention should be drawn to the proportion of social insurance costs in labour costs. Despite the increase in social insurance costs incurred by firms, the proportion this increase represents in total labour costs is not very apparent.

\section{Effects of the implementation of the Law on corporate cost of law violation}

The corporate cost of law violation refers to costs arising from a firm's violation of relevant provisions in the Law. Firms that violate the Law will be heavily penalised. The cost of law violation does not apply to all firms. Firms that have breached the Law will incur such costs, whereas firms that comply with the requirements in labour employment under the Law do not have to bear any cost of law violation. The cost of law violation mainly includes the following aspects:

(a) According to Article 46 of the Law, if workers terminate their labour contracts pursuant to Article 38 herein, the firm will financially compensate the workers. If a firm violates Article 38, a worker can terminate the labour contract, and the firm must pay compensation to the employee. The compensation is calculated at a rate of one month's wages for each full year of service in the firm. Firms have to pay a penalty if they fail to pay the social insurance of workers or overtime work wages in full.

(b) According to Article 87 of the Law, a firm must pay twice the required severance to its workers if it violates the Law upon terminating a labour contract. The required severance pay to a worker is based on the number of years of service in the firm at the rate of one month's wages for each full year of service. As such, when violating the Law, a firm will be penalised by paying its workers double the required severance. Given that the Law has not been implemented for a lengthy period of time, the ratio of this expenditure borne by firms in terms of total labour costs will not be high. However, possible hidden costs that arise from such compensation could be a financial burden on firms. In fact, workers in some large firms might instigate other workers to cause problems in order to receive economic compensation. They could make minor mistakes in their work to force the firm to terminate their labour contracts, and thereby allow them to obtain economic compensation. Firms that pay compensation to such workers may experience potential problems of moral hazard.

(c) According to Article 82 of the Law, a firm pays double the wages each month to its workers if it does not sign a labour contract with them on time, or signs a labour contract with workers without an end date for employment. Such a penalty payment will take effect from the date on which the firm commenced employing them. If a firm follows the guidelines and regulations and abides by the Law, then it will not have to pay any costs incurred by law violation.

14. With regards to the advantages of flexibility in employment policies to firms through the hiring of temporary workers in production work, Mok and Yeung found that firms in southern China experience a higher level of economic performance in terms of technical efficiency. See Vincent Mok and Godfrey Yeung "Employee Motivation, External Orientation and the Technical Efficiency of Foreign-Financed Firms in China: A Stochastic Frontier Analysis," Managerial and Decision Economics, vol. 16, no. 3, 2005, pp. 175-190.

15. If the employment term is at least three years or a regular term without a fixed period, the probationary period could be extended to a maximum of six months.

16. Yinhua Sha, "China's Social Security System - Present Status and Issues," in Japan International Cooperation Agency, "Aging Population in Asia: Experience of Japan, Thailand and China," Seminar Report on the Parallel Session at the 8th Annual Global Development Conference, 17 January 2007, Beijing, China. Retrieved on 2 August 2011 (www.jica.go.jp/english/publications/ reports/study/topical/aging/pdf/ aging_04.pdf).

17. Ibid., p. 49.

18. Adam Livermore, "Understanding China's Social Security System," China Briefing, September 2010. Retrieved on 2 August 2011 (http://www.china-briefing.com/news/2010/09/14/chinassocial-security-system. html). For the evolution of China's insurance-based state pension system, see X.Y. Zhang, "Enterprise Pensions in China: History and Challenges," Public Finance and Management, vol. 9, no. 1, 2009, pp. 76-96. 
In the context of using the direct cost accounting method to estimate the effects of the Law on labour costs, some hidden costs could be neglected in the estimate due to the difficulty of compilation. When hidden costs are not taken into account, the results from the direct method are likely to be underestimated. For example, the implementation of the Law sets higher requirements for corporate management in human resources. The hidden costs that a firm needs to bear include the demand for more human resources personnel to handle issues related to the Law in terms of modification and revision of new rules and regulations and strengthening the mechanisms for the mediation and handling of labour disputes. Moreover, a firm needs to shoulder the expense of training workers to understand the obligations and rights of both the employer and the employees as stipulated by the Law.

\section{Analysing the effects of the Law on labour costs by the indirect cost accounting method}

To study the effects of the Law on labour costs by the indirect cost accounting method, we first examined the effects of an increase in minimum wage and a normal increase in salary on the labour costs of a firm. We then deducted the effects of these two factors from the total increase in labour costs during the period of study. The residual increase in labour costs would be the effects of the Law and other "unspecified factors" that are neglected in our discussion on labour costs. ${ }^{(19)(20)}$

\section{Effects of minimum wage adjustment on labour costs of firms}

China has implemented a minimum wage system with the objective of enabling workers to survive and provide their families with basic necessities. The minimum wage system is important because it ensures that workers will receive a reasonable amount of payment without exploitation by employers. In the vast Chinese market, regional governments are given the autonomy to determine and adjust the minimum wage levels in their localities, in order to cater to regional differences in social and economic development, economic growth, unemployment, and cost of living. (21)

In China, many firms have adopted the minimum wage level as the basic wage for their frontline workers. Adjustments to the minimum wage would greatly affect the wages of frontline workers, and also result in labour cost increases in firms. However, there is no obvious association between a usual adjustment in minimum wage and the implementation of the Law. Below is the formula for the statistical compilation of the effects of a minimum wage increase on a firm's labour costs by the indirect method.

\section{Effects of minimum wage on corporate labour costs}

$=[$ (average wages of frontline workers in the base period $x$ number of frontline workers in the reporting period $x$ adjustment of minimum wage)/total corporate labour costs in the base period]

$=\{$ total wages of frontline workers in the base period $\times(1+$ growth rate of number of frontline workers) $\times$ adjustment of minimum wage]/total corporate labour cost in the base period\}

\section{Effects of a normal increase in salary on labour costs of firms}

When salary experiences an annual growth trend, it will inhibit some effects of the labour costs of firms. We consider that while the wages of frontline workers are affected by a regular adjustment to the minimum wage, non-frontline employees are all influenced by annual salary growth. The effects of a normal increase in the salaries of non-frontline employees on corporate labour costs can be calculated with the following formula:

Effects of a normal increase in salaries of non-frontline employees on corporate labour costs

$=\{[$ (growth rate of monthly average salary of all employees in the base period +1 ) $\times$ average salary of non-frontline workers in the base period $x$ number of non-frontline employees during the reporting period - total salary of non-frontline employees in the base period] /total labour cost in the base period\}

$=\{[$ (growth rate of monthly average salary of all employees in the base period +1$) \times$ total salary of non-frontline employees in the base period $x(1+$ growth rate of non-frontline employees) total salary of non-frontline workers in the base period]/total labour cost in the base period\}

When analysing the effects of the Law on labour costs by the indirect method, we eliminate the effects of a minimum wage adjustment and the annual growth of the average salary of all employees. The residual increase in labour costs would be attributed to the effects of the Law and other unspecified factors on corporate labour costs per capita. However, neither the effects of the Law nor other unspecified factors on corporate labour costs per capita can be isolated. Hence, using the indirect method will result in over-estimates.

\section{Analysing the effects of the Law on labour costs by the range estimation method}

We have examined the effects on labour costs of implementation of the Law from two perspectives by using the direct and indirect cost accounting methods. The direct method indicates that the effects are low, whereas the indirect method indicates more significant effects. Neither method used to examine the effects of the Law on the labour costs of a firm indicates difficulties in identifying accurately estimated values for empirical discussion. As such, it would be appropriate to compile a range of percentiles of the estimated effects to serve as a benchmark range, i.e., giving a range of the effects of the Law on labour costs. The lower range is the result of the direct method of estimation, and the upper range is that from the indirect method. Based on this, we could effectively calculate the range of the effects of the Law on corporate labour cost per capita in China, which would then facilitate policy evaluation.

19. To put it more specifically, costs created by the new Labour Contract Law = Residual costs in the reporting period - Residual costs in the base period $=$ (Total labour costs in the reporting period - "Usual" salary costs in the reporting period) - (Total labour costs in the base period - "Usual" salary costs in the base period) $=$ (Total labour costs in the reporting period - Total labour costs in the base period) - ("Usual" salary costs in the reporting period - "Usual" salary costs in the base period) = increase in total labour costs - increase in "usual" salary costs. The authors would like to acknowledge the helpful comments from an anonymous reviewer on this point.

20. By doing so, the results of compiling the residual labour costs are indeed strong and the results will be over-estimated. Bearing this caveat in mind, the results have to be interpreted with caution.

21. Among others, see Zhaozhou Han, Wages and Social Security: An Investigation into Guangdong Minimum Wages and Research on the Statistical Estimation Models, Beijing, Economics Sciences Publishing Company, 2006. 
Table 1 - Total number of firms in Guangdong Province in 2006 and the proportion of sampling

\begin{tabular}{|l|c|c|c|}
\hline \multicolumn{1}{|c|}{ Locality } & Total number of firms & Number of sample firms & $\begin{array}{c}\text { Proportion of } \\
\text { sample firms (\%) }\end{array}$ \\
\hline Guangdong Province & 529,196 & 600 & 0.1134 \\
\hline (a) Pearl River Delta & & & 0.0749 \\
\hline Guangzhou & 106,879 & 80 & 0.0831 \\
\hline Shenzhen & 96,287 & 80 & 0.1745 \\
\hline Dongguan & 45,851 & 80 & 0.1225 \\
\hline Foshan & 57,143 & 70 & 0.2308 \\
\hline Zhongshan & 21,663 & 50 & 0.1339 \\
\hline Huizhou & 22,410 & 30 & 0.1438 \\
\hline (b) Eastern Guangdong Province & & & 0.4132 \\
\hline Shantou & 20,864 & 30 & 0.2254 \\
\hline Heyuan & 7,261 & 30 & 0.2664 \\
\hline (c) Western Guangdong Province & & & 0.2729 \\
\hline Zhanjiang & 13,311 & 30 & \\
\hline Maoming & 11,263 & 30 & 0.2863 \\
\hline Zhaoging & 10,992 & 30 & 0.3210 \\
\hline (d) Northern Guangdong Province & & & 0.1383 \\
\hline Shaoguan & 10,480 & 30 & \\
\hline Qingyuan & 9,347 & 600 & \\
\hline Sub-total of (a) to (d) & 433,751 & & \\
\hline Source: Statistics Buraa of Guangdong Province, China Guangdong Statistical Yearbook 2007 & & \\
\hline
\end{tabular}

Source: Statistics Bureau of Guangdong Province, China, Guangdong Statistical Yearbook 2007.

Table 2 - Classification of large, medium and small firms

\begin{tabular}{|c|c|c|c|c|c|}
\hline Economic sector & Indicator & Unit & Large & Medium & Small \\
\hline Manufacturing & $\begin{array}{l}\text { Employee } \\
\text { Sales } \\
\text { Total assets }\end{array}$ & $\begin{array}{c}\text { Person } \\
10,000 \text { yuan } \\
10,000 \text { yuan }\end{array}$ & $\begin{array}{l}>2,000 \\
>30,000 \\
>40,000\end{array}$ & $\begin{array}{l}300-2,000 \\
3,000-30,000 \\
4,000-40,000\end{array}$ & $\begin{array}{l}<300 \\
<3,000 \\
<4,000\end{array}$ \\
\hline Construction & $\begin{array}{l}\text { Employee } \\
\text { Sales } \\
\text { Total assets }\end{array}$ & $\begin{array}{c}\text { Person } \\
10,000 \text { yuan } \\
10,000 \text { yuan }\end{array}$ & $\begin{array}{l}>3,000 \\
>30,000 \\
>40,000\end{array}$ & $\begin{array}{l}600-3,000 \\
3,000-30,000 \\
4,000-40,000\end{array}$ & $\begin{array}{l}<600 \\
<3,000 \\
<4,000\end{array}$ \\
\hline Wholesaling & $\begin{array}{l}\text { Employee } \\
\text { Sales }\end{array}$ & $\begin{array}{c}\text { Person } \\
10,000 \text { yuan }\end{array}$ & $\begin{array}{l}>200 \\
>30,000\end{array}$ & $\begin{array}{l}100-200 \\
3,000-30,000\end{array}$ & $\begin{array}{l}<100 \\
<3,000\end{array}$ \\
\hline Retailing & $\begin{array}{l}\text { Employee } \\
\text { Sales }\end{array}$ & $\begin{array}{c}\text { Person } \\
10,000 \text { yuan }\end{array}$ & $\begin{array}{l}>500 \\
>15,000\end{array}$ & $\begin{array}{l}100-500 \\
1,000-15,000\end{array}$ & $\begin{array}{l}<100 \\
<1,000\end{array}$ \\
\hline Transportation & $\begin{array}{l}\text { Employee } \\
\text { Sales }\end{array}$ & $\begin{array}{c}\text { Person } \\
10,000 \text { yuan }\end{array}$ & $\begin{array}{l}>3,000 \\
>30,000\end{array}$ & $\begin{array}{l}500-3,000 \\
3,000-30,000\end{array}$ & $\begin{array}{l}<500 \\
<3,000\end{array}$ \\
\hline $\begin{array}{c}\text { Hotel, } \\
\text { food and beverage }\end{array}$ & $\begin{array}{l}\text { Employee } \\
\text { Sales }\end{array}$ & $\begin{array}{c}\text { Person } \\
10,000 \text { yuan }\end{array}$ & $\begin{array}{l}>800 \\
>15,000\end{array}$ & $\begin{array}{l}400-800 \\
3,000-15,000\end{array}$ & $\begin{array}{l}<400 \\
<3,000\end{array}$ \\
\hline
\end{tabular}

Source: China National Bureau of Statistics website, http://www.stats.gov.cn/tjbz/t20061018_402369829.htm (consulted in August 2011).

\section{Statistical and empirical analysis of the effects of the Law on labour costs}

A set of data on firms collected in the Guangdong Province is used to estimate the effects of the Law on labour costs. Why did we choose Guang- dong Province for our study? There are two main reasons. First, undertaking empirical studies on data at the firm level in China is often contingent on being able to gain access to firms. The local government units have good access to firms, which made the collection of data more feasible when help from the local government departments was available to re- 
Table 3 - Analysis of the effects of the Labour Contract Law on the labour costs of production in 13 regions in Guangdong Province (Direct cost accounting method) (\%)

\begin{tabular}{|c|c|c|c|c|c|c|c|c|c|c|c|c|c|c|}
\hline $\begin{array}{c}\text { Cost } \\
\text { increase }\end{array}$ & 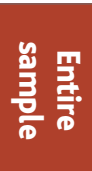 & 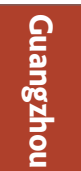 & $\begin{array}{l}\frac{0}{0} \\
\frac{1}{3} \\
\frac{0}{3}\end{array}$ & 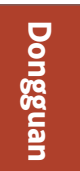 & 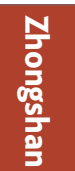 & 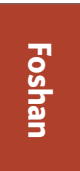 & $\begin{array}{l}n \\
\frac{0}{2} \\
\frac{0}{2}\end{array}$ & 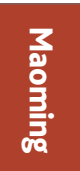 & 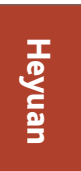 & $\begin{array}{l}\text { N } \\
\text { 영 } \\
\text { 롤. }\end{array}$ & 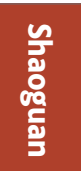 & 을 & Nㅜㄹ & $\frac{\text { T․ }}{\text { 출 }}$ \\
\hline (a) & 0.10 & 0.08 & 0.18 & 0.14 & 0.13 & 0.13 & 0.10 & 0.10 & 0.11 & 0.08 & 0.09 & 0.09 & 0.10 & 0.07 \\
\hline (b) & 2.57 & 2.03 & 2.24 & 3.23 & 2.59 & 2.50 & 1.62 & 1.57 & 2.61 & 2.19 & 2.24 & 1.46 & 1.66 & 2.03 \\
\hline (c) & 0.05 & 0.09 & 0.06 & 0.08 & 0.10 & 0.05 & 0.18 & 0.00 & 0.05 & 0.31 & 0.03 & 0.00 & 0.16 & 0.21 \\
\hline (d) & 2.72 & 2.20 & 2.48 & 3.45 & 2.82 & 2.68 & 1.90 & 1.67 & 2.77 & 2.58 & 2.36 & 1.55 & 1.92 & 2.31 \\
\hline (e) & 2.54 & 2.06 & 2.32 & 3.28 & 2.66 & 2.51 & $1 . .75$ & 1.57 & 2.60 & 2.41 & 2.20 & 1.46 & 1.80 & 2.17 \\
\hline
\end{tabular}

(a) Ratio of direct increase in labour cost to total labour costs of firms; (b) Ratio of regressive cost to total labour costs of firms; (c) Ratio of cost of law violation to total labour costs of firms; (d) Ratio of cost increase to total labour cost of firms $(d=a+b+c)$; (e) Ratio of increase in total cost per capita due to the Law.

Table 4 - Analysis of the effects of the Labour Contract Law on the labour costs of production in 13 regions in Guangdong Province (Indirect cost accounting method) (\%)

\begin{tabular}{|c|c|c|c|c|c|c|c|c|c|c|c|c|c|c|}
\hline $\begin{array}{c}\text { Cost } \\
\text { increase }\end{array}$ & 兽 & $\begin{array}{l}\text { 올 } \\
\text { 总 } \\
\text { 올 }\end{array}$ & 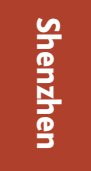 & 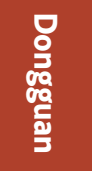 & 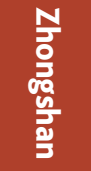 & $\begin{array}{l}\text { 꿍 } \\
\text { ํㅜㄹ } \\
\text { 입 }\end{array}$ & 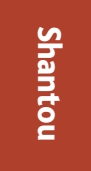 & 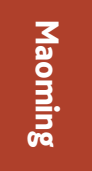 & 폴 & $\begin{array}{l}\text { N } \\
\text { 융. } \\
\text { 蛋 }\end{array}$ & 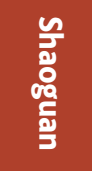 & 올 & 술 & 돌. \\
\hline (a) & 16.13 & 15.35 & 14.25 & 19.91 & 15.39 & 16.25 & 16.08 & 14.17 & 17.26 & 14.81 & 14.07 & 14.93 & 13.48 & 13.56 \\
\hline (b) & 4.64 & 4.13 & $0 *$ & 5.80 & 3.09 & 3.86 & 5.17 & 4.05 & 6.12 & 4.01 & 4.80 & 4.10 & 4.00 & 4.38 \\
\hline (c) & 6.58 & 7.38 & 9.30 & 7.65 & 6.62 & 6.69 & 6.43 & 6.33 & 6.98 & 6.54 & 5.26 & 7.83 & 6.08 & 5.31 \\
\hline (d) & 4.90 & 3.84 & $4.95^{*}$ & 6.47 & 5.68 & 5.70 & 4.48 & 3.79 & 4.16 & 4.26 & 4.01 & 3.00 & 3.40 & 3.88 \\
\hline
\end{tabular}

1. (a) the total increase of labour costs per capita in firms; (b) the increase in labour cost per capita due to an increase in minimum wage; (c) the increase in labour cost per capita due to a normal increase in salary; and (d) the increase in labour cost per capita due to the effects of the Law and other unspecified factors ( $d=a-b-c)$.

2. *The upward adjustment to the minimum wage level in Shenzhen was executed on 1 July 2008 , which was very close to the time of our questionnaire survey. As a result, our survey data were not able to cater to the effects of the increase in minimum wage on labour costs in firms in Shenzhen.

searchers. Second, since China introduced economic reforms in 1979, Guangdong Province has enjoyed a higher level of economic freedom than other provinces. It is one of the provinces that have attracted the largest amount of foreign direct investments into China.

In 2008, with financial support from the Guangdong Provincial Government and the assistance of various government departments, including the Guangdong Labour and Social Guarantee Bureau, Guangdong Statistical Bureau, and the Guangdong Survey Brigade of the China National Bureau of Statistics, we conducted an in-depth questionnaire survey across different economic categories and industries in 13 major cities in the Pearl River Delta and in the eastern, western, and northern regions of Guangdong Province. The 13 cities are Guangzhou, Shenzhen, Dongguan, Zhongshan, Foshan, Shantou, Maoming, Heyuan, Zhaoqing, Shaoguan, Qingyuan, Zhanjiang, and Huizhou. In terms of output, the contribution of these 13 cities to the total GDP of Guangdong Province in 2009 was as great as 78 percent. (22)

In terms of the sampling in our survey, the number of firms established in the 13 cities served as a base for the allocation of sample firms. To obtain an acceptable representation of firms in each city, the minimum number of questionnaires to be collected from each of the 13 cities was set at 30. For large cities such as Guangzhou, Shenzhen, and Dongguan, we sur- veyed 80 firms in each city. Following these guidelines, the proportion of samples is depicted in Table 1. The total number of questionnaires was 600 . There were 561 valid questionnaires completed through on-site visits. Moreover, we collected 45 valid questionnaires from firms via the Internet. In terms of the survey given to frontline workers, we interviewed five workers randomly selected from each sample firm and obtained 2,922 valid questionnaires. In our paper, a frontline worker is defined as an average worker who directly engages in the production of goods or provision of services. For instance, a frontline worker of a manufacturing firm typically has to handle equipment for the assembling and processing of products. In the first half of 2008 , the minimum and average salaries of the workers involved in our survey were 580 yuan and 1375.73 yuan, respectively. ${ }^{(23)}$ Our data set covered large, medium, and small firms comprising 15 percent, 60 percent, and 25 percent of the total sample, respectively. For the identifi-

22. Statistics Bureau of Guangdong Province, China, Guangdong Statistical Yearbook 2010.

23. There were five statutory minimum wage levels ranging from 530 to 860 yuan a month implemented in various regions in Guangdong Province in 2008. The minimum wage of 580 yuan was adopted in ten cities, among which five were included in our sample regions: Heyuan, Zhanjiang, Maoming, Zhaoging, and Qingyuan. Retrieved on 6 August 2011 (http://wenku.baidu.com/ view/12499dbc960590c69ec37660.html). 
Table 5 - Range of the effects of the Labour

Contract Law on the labour costs of production in 13 regions in Guangdong Province (\%)

\begin{tabular}{|c|c|c|c|}
\hline City & $\begin{array}{l}\text { Range of the } \\
\text { effects of the } \\
\text { Labour Contract } \\
\text { Law on labour } \\
\text { cost per capita } \\
(\%)\end{array}$ & City & $\begin{array}{l}\text { Range of the } \\
\text { effects of the } \\
\text { Labour Contract } \\
\text { Law on labour } \\
\text { cost per capita } \\
\text { (\%) }\end{array}$ \\
\hline Entire sample & $2.54-4.90$ & Maoming & $1.57-3.79$ \\
\hline Guangzhou & $2.06-3.84$ & Heyuan & $2.60-4.16$ \\
\hline Shenzhen & $2.32-4.95$ & Zhaoqing & $2.41-4.26$ \\
\hline Dongguan & $3.28-6.47$ & Shaoguan & $2.20-4.01$ \\
\hline Zhongshan & $2.66-5.68$ & Qingyuan & $1.46-3.00$ \\
\hline Foshan & $2.51-5.70$ & Zhanjiang & $1.80-3.40$ \\
\hline Shantou & $1.75-4.48$ & Huizhou & $2.17-3.88$ \\
\hline
\end{tabular}

cation of firm size, we followed the guidelines of classification of a large, medium, and small firm adopted by the China National Bureau of Statistics (Table 2). From the questionnaire survey, we were able to collect economic data at the firm level in the first half of 2007 and the first half of 2008, which were labelled the base and the reporting periods, respectively. The data included the costs of hiring workers, management, social security, training, contract termination, etc. ${ }^{(24)}$ The data were allocated to the three types of cost instigated by the Law, i.e., direct increases in labour costs, regressive costs, and cost of law violation. The results of our empirical study based on the survey data are discussed below.

\section{Empirical results of the effects of the Law on corporate} labour costs by using the direct cost accounting method

After analysing the field survey data from the 13 cities with the direct method, we found that implementation of the Law has had limited effect on corporate labour costs, as shown in Table 3. The results indicate that the effects of the Law on corporate labour costs vary in different regions of Guangdong Province. Dongguan City had the highest share of increase in corporate total costs due to implementation of the Law relative to total labour costs among the sample regions, amounting to 3.45 percent. If the growth in the number of employees is removed as a factor, the ratio of the increase in total cost per capita to the total labour cost is 3.28 percent. This is the highest among all the sample regions. Qingyuan experienced the smallest effects of the Law on the increase of corporate labour costs, at a magnitude of 1.46 percent. The pertinent average effect is 2.54 percent.

\section{Empirical results of the effects of the Law on corporate} labour costs by using the indirect cost accounting method When the indirect method was applied to analyse the data set, we obtained the effects of the Law and other unspecified factors on corporate labour cost per capita. It was found that Dongguan City had the highest share of increase in labour cost per capita due to implementation of the
Table 6 - Range of the effects of the Labour Contract Law on the labour costs of production by economic sector in Guangdong Province (\%)

\begin{tabular}{|l|l|}
\hline \multicolumn{1}{|c|}{ Economic Sector } & $\begin{array}{c}\text { Range of the } \\
\text { effects of the } \\
\text { Labour Contract } \\
\text { Law on labour } \\
\text { cost per capita } \\
(\%)\end{array}$ \\
\hline Entire sample & $2.54-4.90$ \\
\hline Manufacturing & $2.80-5.76$ \\
\hline Construction & $2.05-3.24$ \\
\hline $\begin{array}{l}\text { Wholesale, retail, food } \\
\text { and beverage }\end{array}$ & $2.65-5.20$ \\
\hline $\begin{array}{l}\text { Services including hotel, travel, } \\
\text { and entertainment }\end{array}$ & $2.73-4.18$ \\
\hline Source: Authors' compilation. & \\
\hline
\end{tabular}

Law and other unspecified factors relative to total labour costs, and was the highest among the sample regions, with a record 6.47 percent. Qingyuan recorded a 3.00 percent increase on corporate labour costs, which was the smallest. On average, the pertinent effect of the Law on raising corporate labour costs was 4.90 percent. The results are presented in Table 4.

\section{The range of the estimated effects}

Based on the results presented in Tables 3 and 4, we re-compiled the range of the estimated effects of the implementation of the Law on labour costs of firms in the 13 cities, with the results shown in Table 5. The lower end of the range is the result based on the direct cost accounting method, while the upper end of the range is based on the indirect method. After a comparison against the results in Table 5, we found that the effects of the Law on labour costs of firms in our entire sample in Guangdong Province were in the range of 2.54 percent to 4.90 percent. Dongguan City recorded the largest effects of the Law, with a range of 3.28 percent to 6.47 percent, whereas Qingyuan experienced the smallest pertinent effects, between 1.46 percent and 3.00 percent.

The empirical findings of an investigation on the effects of the Law on corporate labour costs by economic sector, i.e., manufacturing, construction, wholesale and retailing in food and beverage, and services sectors including hotel, travel, and entertainment, are shown in Table 6.

From Table 6, we find that among the four economic sectors, manufacturing firms experienced relatively large increases in corporate labour costs per capita, which ranged from 2.80 percent to 5.76 percent, due to implementation of the Law as indicated by the higher values in both the lower and upper bounds of the range.

24. It has to be noted that some enterprises may pretend to comply with government regulations. If so, the cost of penalties reported in the survey would likely be on the low side of the actual figures. The authors of this paper would like to thank an anonymous reviewer for drawing attention to this point when interpreting the survey results. 


\section{Explanations of the empirical findings}

Along with rapid economic growth, firms in China experience increases in the cost of production over time. A World Bank survey indicated that payments to workers in China have increased significantly by 12 percent each year since 2000, overtaking the relatively low single-digit growth rate in the 1990s. Since the mid-2000s, the growth rate of wage payment has overtaken productivity and thus diminished profit margins for firms. ${ }^{25)}$ Since its implementation, many firms have attributed the increase in their labour costs of production to the Law. Many firms have openly complained about the Law. ${ }^{(26)}$ However, such grievances are clouded by a paucity of data and empirical evidence. According to our empirical study, the effects of the Law on labour costs of firms in different regions in Guangdong Province are not particularly large, incurring an increase in the corporate labour cost per capita ranging between 2.54 and 4.90 percent. The results suggest that implementation of the Law is not the primary source of increase in the total cost of production in southern China. (27)

Immediately after implementation of the Law, many firms predicted that it would exert grave impact on labour costs. Hence, their severe opposition to the Law was not unexpected. Indeed, the Law aims to clarify the obligations and rights of workers and firms, protect the lawful rights of workers, and strengthen and stabilise labour relations, and consequently lays a solid foundation for building a harmonious society. To achieve this target, the Law has re-adjusted the pattern of vested interests among workers and firms. Doing so may have exacerbated the interests of one or the other party. This is the unavoidable price paid for implementing the Law. Modern corporations, for instance those supporting corporate social responsibility, are different from "sweatshops." (28) The ultimate target of sweatshops is to make profit, whereas that of many modern corporations is to achieve high value for all stakeholders in the corporation. Sweatshops treat employees as parts of a machine, whereas many modern corporations regard employees as their members. ${ }^{(29)}$ Modern corporations also reflect their values by practicing corporate social responsibility. In view of the current situation in China, some articles in the Law are ahead of the current stage of industrial relations. As a result, some firms have found it difficult to cope with the Law's provisions in the initial stage of implementation.

\section{Concluding remarks}

Since the launch of economic reform, China has achieved substantial economic growth largely based on its advantage of low-cost production in the labour market. Employment creation has always been the primary target of the state for the sake of maintaining social stability. While lowvalue-added labour-intensive processing industries are able to support more employment, the laws and regulations pertinent to the labour market are not strongly enforced to protect the interests and rights of workers. Advancing into the twenty-first century, the Chinese government has realised that economic development in the future should not depend solely on low-value-added labour-intensive processing industries, as low-skilled, low-cost, and low-margin manufacturing productions are easily replaceable. ${ }^{\left({ }^{30}\right)}$ Besides, if hundreds of millions workers are not adequately protected, job creation alone may not guarantee social stability. ${ }^{(31)}$ Consequently, the government has shifted its development strategy to high-level technology-based industrial production and stable employment relationships in the longer term for social cohesion and harmony. Against this background, the Chinese government adopted the Labour Contract Law in
January 2008 in order to improve, strengthen, and stabilise employment relations.

During the initial stage of implementation of the Law in 2008, many did not see its benefits. Many firms reacted strongly, indicating that the Law would have grave impact on their production and oblige them to leave the Chinese market. As a consequence, hundreds of thousands of workers would be thrown out of jobs and find themselves unemployed, which would threaten social stability. Could the Law actually cause such concern? This paper was an attempt to empirically study the effects of the Law on corporate labour costs by employing a data set collected in various cities in Guangdong Province. Our findings suggest that the increased labour costs per capita due to the effects of the Law do not appear to be economically significant, falling into a range of 2.54 to 4.90 percent. This empirical evidence refutes the concern and discontent of firms regarding the impact of the Law on their labour costs of production. Although the current study results are drawn from a survey conducted in Guangdong Province, the findings should be of interest to firms and government departments in other localities as well.

Nonetheless, would the exit of some firms from the Chinese market threaten social stability? Liisi Karindi acknowledged that

... this outcome might well be the indirect aim of the Chinese Government. According to Wen Jiabao's speech at a press conference on the $11^{\text {th }}$ Five-Year Plan, China will prohibit, punish and close down energy wasting and highly polluting enterprises. Most of the labourintensive production companies, for example in the manufacturing sector, belong to this category... (32)

In fact, many firms that have left the Chinese market are involved in lowend manufacturing. ${ }^{(33)}$ While the underlying motivation for the Labour Contract Law is to protect and strengthen employment relations for the sake of social stability in the longer term, its implementation could trigger a re-structuring of China's industrial sector.

25. Quoted in Yu-fu Chen and Michael Funke, "China's New Labour Contract Law: No Harm to Employment?" op. cit., p. 568. Also see Alexandra Harney, "Bye Bye Cheap Labor," Far Eastern Economic Review, vol. 171, no. 2, March 2008, pp. 29-32.

26. Edward Wong, "Factories Shut, China Workers Are Suffering," New York Times, 14 November 2008.

27. However, for some firms, a 2-4 percent increase in labour costs could be interpreted as quite significant, in particular when the firms' productions are labour-intensive.

28. The Economist produced a special report on the corporate social responsibility system. See The Economist, "A Special Report on Corporate Social Responsibility," vol. 386, no. 8563, 19-25 January 2008, p. $52 \mathrm{ff}$.

29. Among others, see Chatzis, who reviews the writings of Pierre Naville, a French sociologist. Konstantinos Chatzis, "Rationalizing Maintenance Activities within French Industry During the Trente Glorieuses, 1945-75," Journal of History of Science and Technology, vol. 2, Fall 2008, pp. 75-138.

30. Yu-fu Chen and Michael Funke, "China's New Labour Contract Law: No Harm to Employment?" op. cit., p. 570 .

31. Auret van Heerden "Impact of the Economic Crisis on China's Labor Contract Law," Global Action Blog, 9 March 2009. Retrieved on 28 March 2011 (http://globalaction4fairlabor.wordpress.com/ 2009/03/09/impact- of- the-economic-crisis-on-chinas-labor-contract-law).

32. Liisi Karindi, op. cit., p. 13.

33. Alexandra Harney, op. cit., pp. 31-32; Shuguang Du, "Will the Implementation of Labor Contract Law Trigger the Industrial Restructuring?" Shanghai Enterprise, vol. 12, 2007, pp. 5-7. 